\title{
STANDARDIZATION OF THE DYE TEST FOR TOXOPLASMOSIS
}

\author{
BY \\ J. K. A. BEVERLEY AND C. P. BEATTIE \\ From the Bacteriology Department, The University, Sheffield
}

(RECEIVED FOR PUBliCATION AUGUST 9, 1952)

With the ever-increasing interest being taken in toxoplasmosis more and more requests are reaching laboratories for help in its diagnosis.

Prominent among the diagnostic tests employed is the cytoplasm-modifying-antibody (dye) test introduced by Sabin and Feldman (1948). Briefly, this consists in mixing varying dilutions of the patient's serum with peritoneal exudate rich in Toxoplasma from an inoculated mouse, incubating the mixture, and then adding methylene blue. If the patient's serum contains antibody the Toxoplasma will not take up the dye. We have been using this test since 1949. It has been our aim to control or correct variable factors as far as possible so that the results obtained from day to day may be consistent within our own laboratory. Our immediate hope in writing this paper is that we may help others to overcome difficulties that we have encountered, and our ultimate hope that from studies such as ours there may evolve a universally accepted technique that will produce consistent results between laboratories.

With these objects in view, we propose to discuss the reagents used in the test and to describe modifications we have thought desirable.

\section{Materials and Methods}

Patient's Serum.-When we first started using the Sabin-Feldman test we used freeze-dried specimens in order to preserve the labile, complement-like " accessory factor" present in the patient's own serum. Winsser and Makstenieks's paper (1949) led us to realize that this was unnecessary, as "accessory factor," or "activator" as they call it, can easily be supplied by fresh serum taken from a normal donor. It has not been our practice to inactivate the patient's serum, as we have found no difference between noninactivated serum and serum inactivated for half an hour at $56^{\circ} \mathrm{C}$. Nor have we found the antibody titre of serum to fall during the day or two spent in the post. When received the serum is stored at about $4^{\circ} \mathrm{C}$. Dilutions of serum we make up in saline, not in activator serum, for that would result in varying quantities of activator being present in the dilution tubes, and we have evidence that the amount of activator influences the result.

Activator.-The sera of many normal persons contain antibody in small amounts. Such sera are not suitable as sources of activator. When we are selecting a donor we first mix his fresh serum with mouse peritoneal exudate rich in Toxoplasma, incubate, and then stain. Only if we find that few, if any, Toxoplasma are unstained do we use that person as a donor. Latterly we have developed a pool of suitable donors from members of laboratory staffs and patients with polycythaemia. The separated serum is bottled in 5-ml. amounts and kept at $-20^{\circ} \mathrm{C}$ until required. Thus stored we find that activator retains its potency unimpaired for at least three months.

Dye.-We use the saturated alcoholic solution of methylene blue described by Sabin and Feldman (1948) freshly made on the day the tests are performed, generally while the tests are in the water-bath. We find that even if only 24 hours old the dye tends to form a dirty precipitate with the Toxoplasma suspension-activator-antibody mixture. We have tried six different commercial preparations of methylene blue and find that all give identical results.

Toxoplasma Suspensions. - The strain of Toxoplasma we use was obtained from Dr. Cathie, who states (Cathie and Dudgeon, 1949) that it was originally isolated by Sabin in 1939 from a child who had acute encephalitis.

It is maintained by intraperitoneal passage in mice. four mice being on the average inoculated at one time and the interval between passages being from three to five days. No special strain of mice is used. but we find it important, when we are going to use the peritoneal exudate to provide suspension for the test and not merely for passage, to use mice of 8 to 10 weeks old which have been inoculated three days previously. The reason for this is that we find that antibody, which may interfere with the test, develops in the mouse. The sooner the mouse is killed the less of this there will be. Three days is the earliest time at which an exudate sufficiently rich in Toxoplasma can be obtained. There is no advantage in using an older exudate for its greater volume, since 
the count of stainable Toxoplasma is less. Less antibody is produced in young than in older mice (Table I).

TABLE I

RESULTS IN YOUNG AND OLD MICE

\begin{tabular}{|c|c|c|c|c|c|c|}
\hline \multirow[t]{2}{*}{$\begin{array}{l}\text { Days since } \\
\text { Inoculation } \\
\text { of Mouse }\end{array}$} & \multicolumn{2}{|c|}{$\begin{array}{c}\text { Average Percen- } \\
\text { tage of Unstained } \\
\text { Toxoplasma in } \\
\text { Peritoneal } \\
\text { Exudate }\end{array}$} & \multicolumn{2}{|c|}{$\begin{array}{l}\text { Dye Test on } \\
\text { Mouse Serum } \\
\text { (Average \% } \\
\text { Unstained } \\
\text { Toxoplasma*) }\end{array}$} & \multicolumn{2}{|c|}{$\begin{array}{l}\text { No. of } \\
\text { Mice Used }\end{array}$} \\
\hline & Young & Old & Young & Old & Young & Old \\
\hline $\begin{array}{l}3 \\
4 \\
5\end{array}$ & $\begin{array}{r}2 \\
21 \\
28\end{array}$ & $\begin{array}{l}10 \\
29 \\
58\end{array}$ & $\begin{array}{r}2 \\
9 \\
13\end{array}$ & $\begin{array}{l}12 \\
25 \\
30\end{array}$ & $\begin{array}{l}4 \\
3 \\
4\end{array}$ & $\begin{array}{r}7 \\
8 \\
10\end{array}$ \\
\hline
\end{tabular}

* 1 in 4 dilution of serum, results corrected to 30,000 Toxoplasma $\mathrm{mm} .3$ in exudate.

To prepare the Toxoplasma suspension we kill as many mice as we consider will be required to provide sufficient exudate for the number of tests we have to do. From one mouse we can obtain 0.5 to $1 \mathrm{ml}$. and this is enough for four tests. Should the exudate be scanty, we wash out the peritoneal cavity with about $1 \mathrm{ml}$. of normal saline. The exudate or suspension is heparinized, 2 drops of heparin $(100$ units $/ \mathrm{ml}$. in normal saline) for each mouse exudate, and films are made and stained with polychrome methylene blue. They are examined to make sure that they are rich in Toxoplasnia and that these are mainly extracellular, for intracellular Toxoplasma, not being visibly affected by antibody, are useless in the test.

We make no attempt to standardize the number of Toxoplasma in our suspension. It would be difficult to do this and still use the suspension fresh, nor is it necessary, for we find that, using suspensions varying in content between 1,500 and 90,000 Toxoplasma $\mathrm{mm}^{3}$, there is a direct relation between the number of Toxoplasma and the serum concentration which will modify $50 \%$ of them. We therefore use any suspension with a normal content of Toxoplasma and later, when we are reading the test, determine the Toxoplasma content and correct our results to a standard of 30,000 Toxoplasma $\mathrm{mm}^{3}$

A point of great importance is that the Toxoplasma suspension should be used immediately. Toxoplasma in a suspension which has been allowed to stand at room temperature for 40 minutes are twice as susceptible to the action of antibody.

Setting up the Test.-In order that the Toxoplasma suspension shall be used fresh one worker prepares it while another sets up the serum dilutions.

The technique of the tests may be summarized as follows :

\begin{tabular}{|c|c|c|c|c|c|c|}
\hline Tube & 1 & 2 & 3 & 4 & 5 & 6 \\
\hline $\begin{array}{c}\text { Patient's } \\
\text { serum }\end{array}$ & $\begin{array}{l}2 \text { drops } \\
\text { undiluted }\end{array}$ & $\begin{array}{l}2 \text { drops } \\
1: 2\end{array}$ & $\begin{array}{c}2 \text { drops } \\
1: 4\end{array}$ & $\begin{array}{l}2 \text { drops } \\
1: 8\end{array}$ & $\begin{array}{c}2 \text { drops } \\
1: 16\end{array}$ & - \\
\hline Saline .. & - & - & - & - & - & 2 drops \\
\hline$\overline{\text { Activator }}$ & 4 drops & 4 drops & 4 drops & 4 drops & 4 drops & 4 drops \\
\hline $\begin{array}{c}\text { Toxoplas- } \\
\text { ma sus- } \\
\text { pension }\end{array}$ & 2 drops & 2 drops & 2 drops & 2 drops & 2 drops & 2 drops \\
\hline
\end{tabular}

The tubes are incubated for one hour in a waterbath at $37^{\circ} \mathrm{C}$., and methylene blue added as follows:

\begin{tabular}{c|c|c|c|c|c}
\hline $\begin{array}{c}\text { Methylene } \\
\text { blue .. }\end{array}$ & 6 drops & 6 drops & 6 drops & 6 drops & 6 drops \\
\hline
\end{tabular}

The results are read, the final dilutions being as set out below.

\begin{tabular}{l|l|l|l|l|l|l}
\hline $\begin{array}{c}\text { Final } \\
\text { dilutions }\end{array}$ & $1: 4$ & $1: 8$ & $1: 16$ & $1: 32$ & $1: 64$ & Control \\
\hline
\end{tabular}

With strongly positive sera subsequent tests, including dilutions up to $1: 1,024$, or higher, are made.

The same pipette is used throughout and is washed with saline between measurements of the different reagents.

The reason for one hour's incubation is that intracellular Toxoplasma, if there be any in the suspension. are liberated by disintegration of some of the tissue cells during the first half-hour. A further half-hour must be allowed to permit the antibody to act on them.

After the dye has been added the tubes are put in the refrigerator and each one kept there until we are ready to examine it. We much prefer to make the examination on the day the tests are set up, as the unstained Toxoplasma are then much clearer and less shrivelled than if left until the next day.

Reading the Test.-We are now able to take time to determine the number of Toxoplasma in our suspension. We make a count in a Neubauer counting chamber of the stained extracellular Toxoplasma in the activator control tube. As they take longer to sediment than do red blood corpuscles, time must be allowed for this by leaving the chamber for 10 minutes in the refrigerator.

The percentage of stained and unstained Toxoplasma in the various tubes is next determined. To do this we place two drops on a coverslip and place a slide on top. The slide is then turned over and examined under a 1/6 in. objective with the light cut down. Often there are marked variations in the thickness of the film due to irregularities in the slide or coverslip. We try to examine portions of even thickness. Thick portions tend to give an erroneously high count of stained Toxoplasma, probably because the unstained are less easily seen and because larger Toxoplasma which are less readily modified by antibody are more likely to be found there.

One hundred Toxoplasma are identified in each film and the percentage of stained and unstained noted.

We begin with the control. The percentage unstained there is usually less than 20 . If it is over 30 we discard the test.

Calculation of Results.-We take as our end-point the highest dilution which will modify (prevent staining of $50 \%$ of the Toxoplasma not affected by mouse antibody. Fig. 1 is an example. 


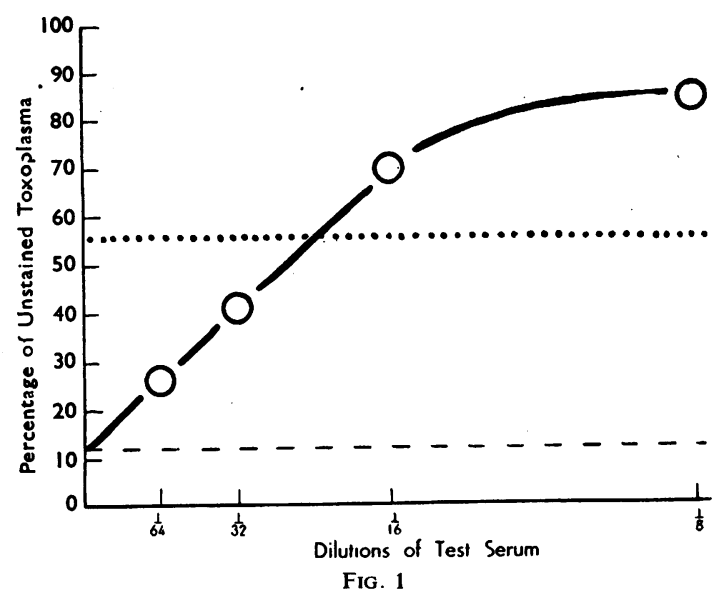

In the control tube $12 \%$ of Toxoplasma were found unstained. Half of the remainder is $44 \%$, to which is added $12 \%$. The end titre will be the serum dilution corresponding to $56 \%$ of unstained Toxoplasma. By interpolation this is found to be a dilution of $1: 21$.

This was, however, for a suspension containing 3,750 stained Toxoplasma in the control tube. Our standard suspension is $30,000(5,000$ in the final mixture). We therefore multiply $1 / 21$ by 5,000 and divide by 3,750 , giving a corrected end titre of $1: 16$.

It should be noted that this is the final dilution of serum after activator and Toxoplasma suspension have been added. Sabin and Feldman (1948) record their results in terms of the original dilution of serum. It would therefore be expected that our end titres would be four times as high, but they dilute their peritoneal exudate $1: 5$. We use ours undiluted. If our contention that there is a direct relationship between the number of Toxoplasma and the amount of antibody necessary to modify them is correct, then our results and theirs should be substantially the same. We have some indication that this is so, for we freeze-dried a few specimens of serum and sent them to Dr. Feldman, who very kindly reconstituted and examined them for us (Table II). When we expected them to reach him we reconstituted duplicate freeze-dried samples and examined them. As it turned out our examination was about three weeks before his.

TABLE II

COMPARISON OF RESULTS IN PRESENT SERIES AND IN SERA EXAMINED BY FELDMAN

\begin{tabular}{|c|c|c|}
\hline No. & Present Result & Feldman's Result \\
\hline $\begin{array}{l}206 \\
207 \\
208 \\
210 \\
212 \\
215 \\
216\end{array}$ & $\begin{array}{l}1: 36 \\
1: 3 \cdot 6 \\
1: 374 \\
\text { Negative } \\
1: 12 \\
1: 164 \\
1: 21\end{array}$ & $\begin{array}{l}1: 64 \text { (between } 1: 64 \text { and } 1: 256) * \\
1: 4 \text { (between } 1: 4 \text { and } 1: 16) \\
1: 1,024(\text { between } 1: 1,024 \text { and } 1: 4,096) \\
\text { Negative } \\
1: 4 \text { (between } 1: 4 \text { and } 1: 16) \\
1: 64 \text { (between } 1: 64 \text { and } 1: 256) \\
1: 16 \text { (between } 1: 16 \text { and } 1: 64 \text { ) } \\
\text {. }\end{array}$ \\
\hline
\end{tabular}

\section{Interpretation}

There should be no difficulty in interpretation in active or recently active congenital or acquired infections. Titres in these cases will be in the hundreds and often in the thousands. Where difficulty does arise is in assessing the significance of lower titres in the serum of persons who have choroido-retinitis or some other clinical condition which may be due to infection with Toxoplasma several years previously. Some "normal" adults are found to have antibody by this test, although in most cases this is found only in low titres (Table III). It is possible that this may be due to nonspecific stimulation. To us it seems more probable that it is specific and due to infection which has not caused clinical manifestations. For a titre to be considered significant it must be shown that it is above that commonly found in persons of the patient's age. We have examined sera from chil-

TABLE III

RESULTS OF TESTS IN "NORMAL” PERSONS

\begin{tabular}{c|c|c|c|c|c|c}
\hline \multirow{2}{*}{ Age } & \multicolumn{5}{|c|}{ Percentage Reacting to a Titre of } & \multirow{2}{*}{ Totals } \\
\cline { 2 - 7 } & $\begin{array}{c}\text { Less than } \\
1: 4\end{array}$ & $\begin{array}{c}1: 4 \text { to } \\
1: 16\end{array}$ & $\begin{array}{c}1: 16 \text { to } \\
1: 32\end{array}$ & $\begin{array}{c}1: 32 \text { to } \\
1: 64\end{array}$ & $\begin{array}{c}\text { Over } \\
1: 64\end{array}$ & \\
\hline $0-9$ & 98 & 1 & 0 & $1^{*}$ & 0 & 106 \\
$10-19$ & $90 \cdot 5$ & $6 \cdot 8$ & $2 \cdot 7$ & 0 & 0 & 73 \\
$20-9$ & 71 & 25 & 2 & 2 & 0 & 101 \\
$30-9$ & 75 & 23 & 1 & 1 & 0 & 105 \\
$40-9$ & 78 & 19. & 3 & 0 & 0 & 108 \\
Over 50 & 71 & 27 & 1 & 1 & 0 & 105 \\
\hline
\end{tabular}

* This child was subsequently found to have a squint.

dren undergoing tonsillectomy, from patients attending ophthalmic out-patient departments for refraction or removal of foreign bodies, none of whom had choroido-retinis or uveitis, from blood donors, and from members of laboratory staffs who did not work with Toxoplasma. From these figures we tentatively deduce that in Great Britain the following titres are likely to be significant.

$$
\begin{array}{cccc}
\text { Under } 10 \text { years .. } & \ldots & \ldots & 1: 16 \text { or over } \\
10-19 \text { years } & \ldots & \ldots & 1: 32,,, \\
\text { Over } 20 \text { years .. } & \ldots & . & 1: 64,,,
\end{array}
$$

Somewhat similar results have been obtained by Westphal (1950) in Germany. Higher figures are given from Sweden by von Zeipel and Linder (1951).

We realize that titres lower than those we are prepared to accept may be given by the sera of patients who have been infected with Toxoplasma in the distant past and are left only with the endresult of that infection. We realize, too, that, as shown "by Sabin and Feldman (1949) and Macdonald (1950), babies born of serologically 
positive mothers may, without themselves being infected, have passively transferred antibodies. In such cases a further test carried out two months later will show their nature either by a marked fall in titre or by the complete disappearance of antibody.

Fuller knowledge of the significance of the Sabin-Feldman test will emerge from its extended use coupled with careful recording of patients' clinical histories and their physical signs and symptoms. So that the results of different workers may be compared it seems desirable that the test should be standardized. We make no claim that ours is the best method of doing this: it is merely an attempt.

\section{Summary}

In order that the results of workers using the Sabin-Feldman cytoplasm modifying (dye) test for the demonstration of antibodies to Toxoplasma may be compared it is desirable that a standard technique should be developed. An inquiry has been made into the variable factors present in the test, and attempts have been made to eliminate or correct them. Suggestions are made for a standard technique.

We tentatively suggest that with our method of carrying out the test the following or higher titres should be regarded as possibly significant up to the age of $10,1: 16$; from 10 to 20 years, $1: 32$; over 20 years, $1: 64$.

It gives us pleasure to express our thanks to the physicians who sent us sera for examination, to Drs. Sabin and Feldman, who most kindly examined certain sera for us, and to Dr. Cathie, who supplied the strain of Toxoplasma.

\section{REFERENCES}

Cathie, I. A. B., and Dudgeon, J. A. (1949). Journal of Clinical Pathology, 2, 259.

Macdonald, A. (1950). Lancet, 2, 560.

Sabin, A. B., and Feldman, H. A. (1948). Science, 108, 660.

Sabin, A. B., and Fediatrics, 4, 660.

Westphal, A. (1950). Z. Tropenmed. Parasit., 1, 526. $15,118$.

Zeipel, G. von, and Linder, L. A. (1951). Acta path. microbiol. scand. , 29, 229. 